EESTI NSV TEADUSTE AKADEEMIA TOIMETISED. 31. KOIDE KEEMIA. 1982, NR. 3

ИЗВЕСТИЯ АКАДЕМИИ НАУК ЭСТОНСКОП ССР. ТОМ 31 ХИМИЯ. 1982, Nㅗ 3

O. POOTC

\title{
ПРЕДВАРИТЕЛЬНЫЕ РАСЧЕТЫ КОЛИЧЕСТВА ПОЛИХЛОРИРОВАННЫХ БИФЕНИЛОВ И ХЛОРОРГАНИЧЕСКИХ ПЕСТИЦИДОВ В БИОМАССЕ БАЛТИЙСКОГО МОРЯ
}

Ускоренное загрязнение Балтийского моря хлорорганическими углеводородами обусловлено двумя основными причинами. Во-первых, размеры моря сравнительно невелики и оно окружено экономически высокоразвитыми странами. Во-вторых, море принадлежит к типу средиземных морей и характеризуется замедленным водообменом (вода в нем обновляется полностью через $17-20$ лет). Относительно низкая температура воды Балтийокого моря в течение всего года снижает биологическую активность воды и создает неблагоприятные условия для разложения хлорорганических пестицидов (ХОП) и полихлорированных бифенилов (ПХБ).

Результаты исследований. Для выяснения общего количества ХОП и ПХБ в гидробионтах и донной растительности пришлось определить их среднегодовые биомассы в Балтийском море. Существенные различия в температурном режиме наблюдаются как между южной и северной, так и между западной и восточной частями Балтики. Они обусловлены климатическими различиями, связанными с большой протяженностью моря в широтном направлении. Кроме этого изменение насыщенности солью - один из ведущих факторов, определяющих состав и распределение фауны и флоры. По вышеуказанным причинам

Таблича 1

Общие данные по морфометрии Балтийского моря и его отдельных частей $[2,3]$

\begin{tabular}{l|r|r}
\hline Части моря & $\begin{array}{r}\text { Площадь, } \\
\kappa \mu^{2}\end{array}$ & $\begin{array}{r}\text { Объем, } \\
\kappa M^{3}\end{array}$ \\
\hline Открытая Балтика & 202000 & 13600 \\
Рижский залив * & 16700 & 460 \\
Финский залив & 29500 & 1125 \\
Ботническое мо- & 80100 & 5195 \\
$\begin{array}{c}\text { ре ** } \\
\text { Ботнический залив }\end{array}$ & 37000 & 1540
\end{tabular}

* Вместе с Ирбенским проливом, Вяйнамери и некоторыми участками устья Финского залива.

** Вместе с Аландским (площадь $5200 \kappa M^{2}$, объем $405 \kappa M^{3}$ ) и Шхеровым (площадь $8300 \kappa \mu^{2}$, объем $195 \kappa м^{3}$ ) «морями».
Таблица 2

Биомасса зообентоса в различных частях Балтики $\left[{ }^{2}\right]$

\begin{tabular}{l|c}
\hline \multicolumn{1}{c|}{ Части моря } & $\begin{array}{c}\text { Бномасса, } \\
2 / \mathrm{M}^{2}\end{array}$ \\
\hline Ботнический залив & 4,9 \\
Ботническое море & 25,7 \\
Финский залив (в целом) & 57,0 \\
Рнжский залив (в целом) & 45,8 \\
Центральная Балтика (в це- & 25,0 \\
лом) & \\
Южная Балтика (в целом) & 60,0 \\
& \\
&
\end{tabular}




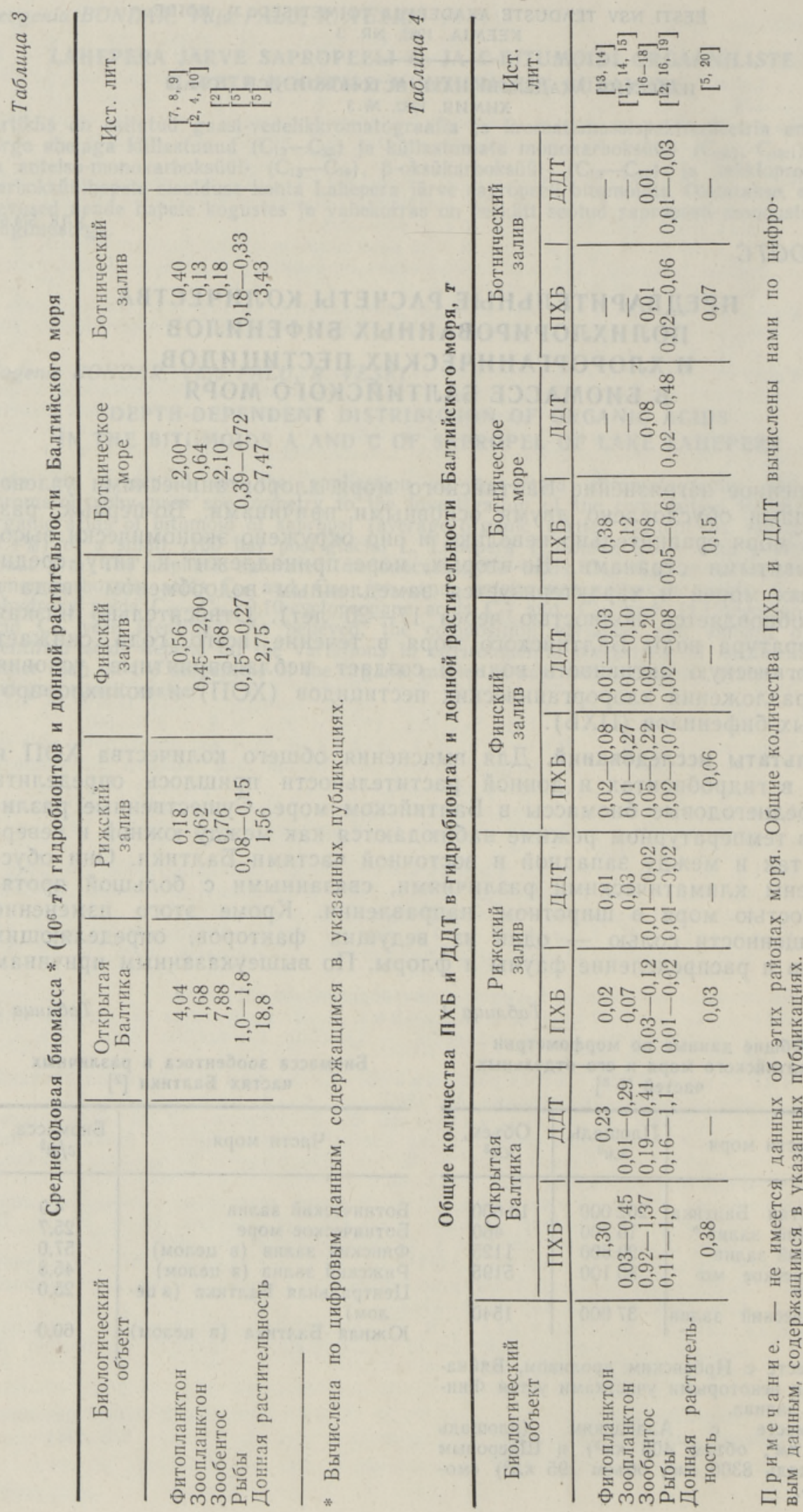


и из-за сложной конфигурации береговой линии, пестрого рельефа дна Балтика подразделяется на несколько естественных районов (табл. 1).

Фитопланктон играет большую роль в жизни водоема, помимо того, что он служит пищей для многих более сложно организованных существ, он еще и важнейший источник кислорода. При вычислении среднегодовой биомассы фитопланктона мы исходили из данных ['], где показано, что фитопланктон Балтийского моря развивается до глубнны $50 \mathrm{\mu}$.

Среднегодовая биомасса зоопланктона зависит от количества фитопланктона, температурного режима, речного стока, и т. д. и состав-

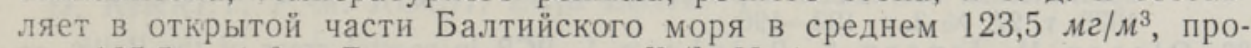

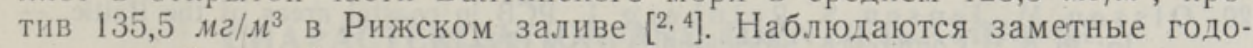
вые колебания биомассы как зоспланктона, так и фитопланктона, Средняя биомасса зообентоса Балтийского моря сравнительно низка, в среднем в открытой части моря 40 г/ $\mathrm{s}^{2}$ (табл. 2).

Чтобы получить биомассу донной растительности отдельных районов моря, мы разделили общую биомассу $34 \times 10^{6} T$ на площади отдельных районов (табл. 1) [5]. Так как климатические условия Ботнического залива суровые, в этом районе моря - повышенная биомасса донной растительности (табл. 3). Общая биомасса рыб Балтийского моря представлена в основном тремя видами: салака, треска и килька. В [5] имеются данные о биомассах рыб только для открытой части моря и Ботнического залива. Содержание ПХБ в гидробионтах и донной растительности различных районов Балтийского моря $4-7$ т (табл. 4). Из суммарного ДДТ его метаболиты ДДД и ДДЕ в планктоне и ихтиофауне составляли в зависимости от района моря $74-87 \%$ [].

\section{Л И ТЕРА Т У Р А}

1. Ннколаев И. И. Фитопланктон Рижского залива. - Тр. Латв. отд. ВНИРО, 1953, вып. 1, с. $115-172$.

2. Я рвекюльг А. Донная фауна восточной части Балтийского моря. Таллин, 1980.

3. Report of the ICES working group on pollution of the Baltic Sea. - Cooper. Res. Report, 1970, Ser, A., N 15, p. $1-66$.

4. Н и кол а е в И. И. Планктон как фактор распределения и продуктивности планктоядных рыб Балтнйского моря. - Тр. совещ. ихтиологич. комиссии АН СССР, 1961, вып. 13, с. $364-373$.

5. Kihlström, J. E., Berglund, E. An estimation of the amounts of $\mathrm{PCB}$ in the biomass of the Baltic. - Ambio, 1978, v. 7, N 4, p. 175-178.

6. Р оотс О. О. Изучение трансформации хлорорганических пестицидов в морской среде. - Гигиена и санитария, 1981, № 3, с. $73-74$.

7. Н иколаев И. И. О «цветенин» воды Балтийского моря. - Тр. Латв. отд. ВНИРО, 1953 , т. 26 , с. $210-220$.

8. Jä rvekülg, A., V e ld re, I. Elu Läänemeres. Tallinn, 1963.

9. Fosskahl, M. Phytoplankton biomass and species compositions in Finnish coastal waters in 1974 and 1975. - Finn. Marine Res., 1980, N 247, p. 94-109.

10. Л у м бер г Л. Ю. О зоопланктоне Финского залива. Рыбохозяйственные исследования в бассейне Балтийского моря. Рига, 1976, вып. 12, с. 10-29.

11. Р оотс О. О., Пейкре Э. А. О содержании устойчнвых бифенилов и пестицидов в зоопланктоне Балтийского моря. Водные ресурсы, 1981, № 6, c. $182-187$.

12. Jensen, S., Johnels, A., Olss on, M., Otterlind, G. DDT and PCB in herring and cod from the Baltic, the Kattegat and the Skagerrak. - Ambio (Special
Report), 1972, N 1, p. 71-87.

13. B r üg g m a n n, L., Lu ckas, B. Zum Vorkommen von polychlorierten Biphenylen und DDT-Metaboliten im Plankton und Wasser der Ostsee. FischereiForschung. Wissenschaftliche Schriftenreihe, 1978, Bd. 16, N 2, S. 31-37.

14. Roots, O. O., Peikre, E. A. The study of the Baltic Sea zooplankton pollution with chlorinated pesticides and polychlorinated biphenyls during the 10th cruise of the R/V \&Ayu-Dag». - In: The Investigation and Modelling of Processes in the Baltic Sea. Tallinn, 1981, part II, p. 131-137. 
f5. Linko, R. R., Rant a mäki, P. Residues in plankton and sediments in the

. (1 . southwestern coast of Finland. $\rightarrow$ Bull. Environm. Contam. and Toxicol., 1974, O70т V: $12, \mathrm{~N} 6$, p. $733 \rightarrow 738$.

16. ICES Cooperative Research Report, 1977, N 63, Denmark, p. 1-54.

17. Root S, O. O. Polychlorinated biphenyls and chlorinated pesticides in mollusc of the Tallinn Bay. - In: The Investigation and Modelling of Processes in the ['] Xia Baltic Sea. Tallinn, 1981, part II, p p $137+141$ :

18. Trzosinska, A. S $l$ a czka, W. Hydrochemical investigations on the Gdansk Basin. III Soviet-Swedish Symposium on the Baltic Sea Pollution, 1975, p. 4453.

19. Р бо т с О., ПН й к ре Э. О содержании полихлорированных бифенилов и хлор-ogn 1978, Tr, 27, № 3, c. 193-196.

20. Oisson, M. Jensen, S., Reinberg, L. PCB in coastal areas, of the Ballic. In: PCB II Conference, Stockholm, 1972, p. 59-69.

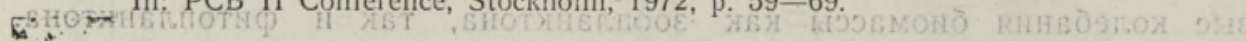

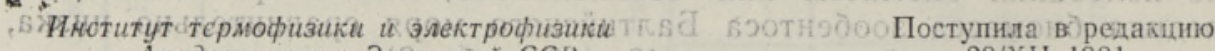
Академии наук Эстонской CCP

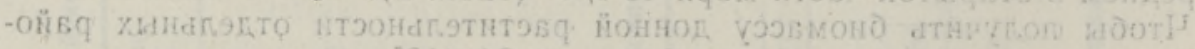

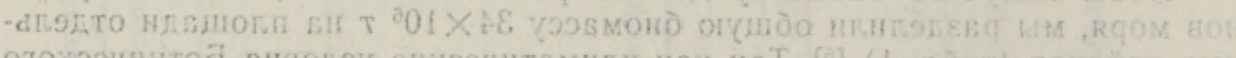

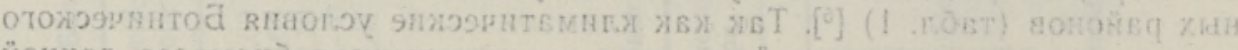

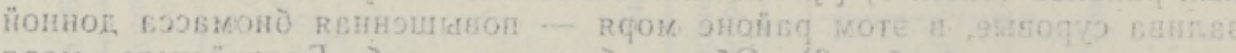

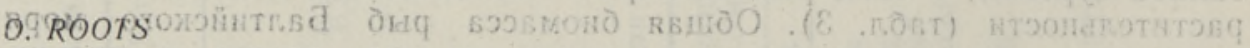

\section{RAANEMERE BIOMASSIS SISALDUVATE POLUKLOREERITUD BIFENOULIDE HOHHO JA KLOORORGAANILISTE PESTITSIIDIDE KOGUSTE ARVUTAMINE}

Artiklis on arvutatud Läanemere eri osade (Soome, Rila ja Botnia lahe ning Läänemere

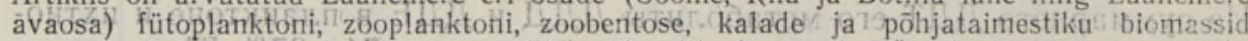
ning nendes sjsalduvatel klobrorgaaniliste ühendite kogused. Fütoplanistoni ja zooplanktoni biomass (aasta keskmise biomassi pōhjal) on vastavalt $7,2 \times 10^{6} \mathrm{t}$ ja $3,5-5,1 \times 10^{6} \mathrm{t}$, zoobentose $12,6 \times 10^{6} \mathrm{t}$, kalade $1,8-3,3 \times 10^{5} \mathrm{t}$ ja põhjataimestiku biomass $34 \times 10^{6} \mathrm{t}$. Polükloreeritud bifenüülide ja kloororgaaniliste pestitsiidide ( $\Sigma$ DDT) kogused Läänemere fütoplanktonis on vastavalt $1,72-1,78 \mathrm{t}$ ja $0,25-0,27 \mathrm{t}$, zooplanktonis $0,23-0,91 \mathrm{t}$ ja $0,05-0,42 \mathrm{t}$, zoobentoses $1,09-1,81 \mathrm{t}$ ja $0,38-0,72 \mathrm{t}$, kalades $0,21-1,76 \mathrm{t}$ ja $0,22-1,61 \mathrm{t}$, põhjataimestikus $0,69 \mathrm{t}$.

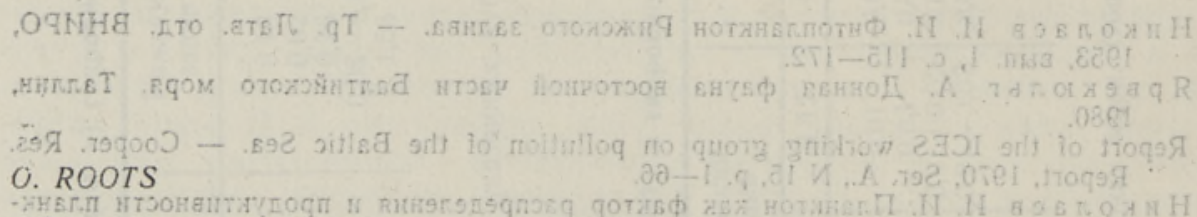

\section{CPRELIMINARY INVESTIGATION OF THE AMOUNTS OF POLYCHLORINATED BIPHENYLS AND CHLORORGANIC PESTICIDES IN THE BIOMASS OF THE BALTIC}

The author worked out the phytoplankton $\left(7.2 \times 10^{6} t\right)$, zooplankton $\left(3.5-5.1 \times 10^{6} \mathrm{t}\right)$, zoobenthic organisms $\left(12.6 \times 10^{6} t\right)$, fish $\left(1.8-3.3 \times 10^{6} t\right)$ and benthic algae $\left(34 \times 10^{6} t\right)$ total biomass and amounts of chlorinated hydrocarbons in the biomass of different parts of the Baltic (Gulfs of Finland, Riga and Bothnia and the Baltic proper). Polychlorinated biphenyl and chlororganic pesticide ( $\Sigma$ DDT) amounts in the phytoplankton are $1.72-1.78 \mathrm{t}$ and $0.25-0.27 \mathrm{t}$, respectively, in the zooplankton $0.23-0.91 \mathrm{t}$ and $0.05-0.42 \mathrm{t}$, in zoobenthic organisms $1.09-1.80 \mathrm{t}$ and $0.38-0.72 \mathrm{t}$, in the fish $0.21-1.76 \mathrm{t}$ and $0.22-1.61 \mathrm{t}$, and in the benthic algae 0.69 .

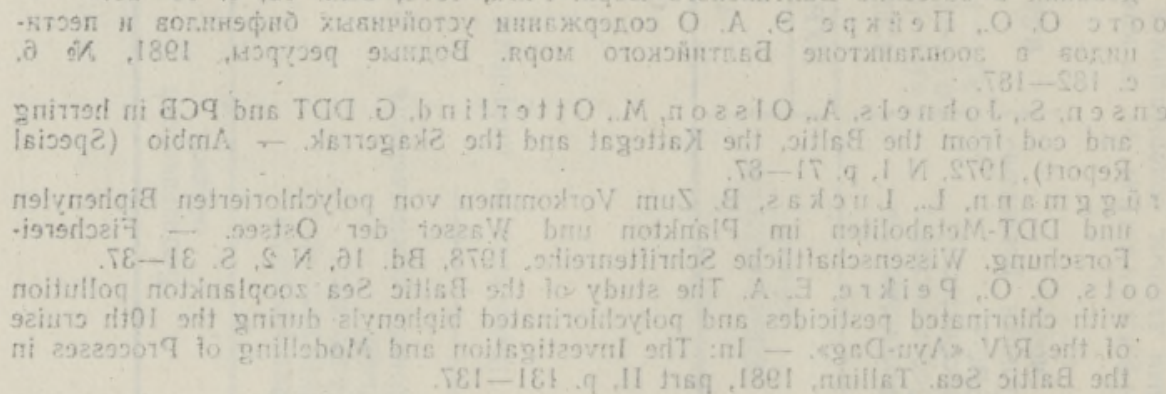

